Oxygen saturation measurements in telemonitoring of patients with COPD: a systematic review

Peer-reviewed author version

Buekers, Joren; DE BOEVER, Patrick; Vaes, Anouk W.; Aerts, Jean-Marie; Wouters, Emiel F. M.; SPRUIT, Martijn A. \& THEUNIS, Jan (2018) Oxygen saturation measurements in telemonitoring of patients with COPD: a systematic review. In: EXPERT REVIEW OF RESPIRATORY MEDICINE, 12(2), p. 113-123.

DOI: $10.1080 / 17476348.2018 .1417842$

Handle: http://hdl.handle.net/1942/26559 


\section{Oxygen saturation measurements in telemonitoring of patients with COPD: a systematic review}

Joren Buekers, Patrick De Boever, Anouk W Vaes, Jean-Marie Aerts, Emiel F.M. Wouters, Martijn A. Spruit \& Jan Theunis

To cite this article: Joren Buekers, Patrick De Boever, Anouk W Vaes, Jean-Marie Aerts, Emiel F.M. Wouters, Martijn A. Spruit \& Jan Theunis (2017): Oxygen saturation measurements in telemonitoring of patients with COPD: a systematic review, Expert Review of Respiratory Medicine, DOI: $10.1080 / 17476348.2018 .1417842$

To link to this article: https://doi.org/10.1080/17476348.2018.1417842

Accepted author version posted online: 15

Dec 2017.

Submit your article to this journal $\pi$

Q View related articles ¿

View Crossmark data 
Publisher: Taylor \& Francis

Journal: Expert Review of Respiratory Medicine

DOI: $10.1080 / 17476348.2018 .1417842$

Review

Oxygen saturation measurements in telemonitoring of patients with COPD: a systematic review

Joren Buekers ${ }^{1,2}$, Patrick De Boever ${ }^{1}$, Anouk W Vaes ${ }^{3}$, Jean-Marie Aerts ${ }^{2}$, Emiel F.M.

Wouters $^{3}$,

Martijn A. Spruit ${ }^{3,4,5}$ and Jan Theunis ${ }^{1}$

${ }^{1}$ Environmental Risk and Health unit, Flemish Institute for Technological Research (VITO), Mol, Belgium

${ }^{2}$ Measure, Model \& Manage Bioresponses (M3-BIORES), Department of Biosystems, KU

Leuven, Leuven, Belgium

${ }^{3}$ Department of Research and Education, CIRO, Horn, the Netherlands

${ }^{4}$ REVAL - Rehabilitation Research Center, BIOMED - Biomedical Research Institute, Faculty of Medicine and Life Sciences, Hasselt University, Diepenbeek, Belgium

${ }^{5}$ Department of Respiratory Medicine, Maastricht University Medical Centre, Maastricht, the Netherlands

*Corresponding author:

Jan Theunis

Flemish Institute for Technological Research (VITO)

Belgium

Email: jan.theunis@vito.be 


\begin{abstract}
Introduction: Telemonitoring applications are expected to become a key component in future healthcare. Despite the frequent use of $\mathrm{SpO}_{2}$ measurements in telemonitoring of patients with chronic obstructive pulmonary disease (COPD), no profound overview is available about these measurements.

Areas covered: A systematic search identified 71 articles that performed $\mathrm{SpO}_{2}$ measurements in COPD telemonitoring. The results indicate that long-term follow-up of COPD patients using daily $\mathrm{SpO}_{2}$ spot checks is practically feasible. Very few studies specified protocols for performing these measurements. In many studies, deviating $\mathrm{SpO}_{2}$ values were used to raise alerts that led to immediate action from healthcare professionals. However, little information was available about the exact implementation and performance of these alerts. Therefore, no firm conclusions can be drawn about the real value of $\mathrm{SpO}_{2}$ measurements. Future research could optimize performance of alerts using individualized, time-dependent thresholds or predictive algorithms to account for individual differences and $\mathrm{SpO}_{2}$ baseline changes. Additionally, the value of performing continuous measurements should be examined.

Expert commentary: Standardization of the measurements, data science techniques and advancing technology can still boost performance of telemonitoring applications. All these opportunities should be thoroughly explored to assess the real value of $\mathrm{SpO}_{2}$ in $\mathrm{COPD}$ telemonitoring.
\end{abstract}

Keywords: COPD; Chronic Obstructive Pulmonary Disease; Telemonitoring; Remote monitoring; Oxygen saturation; Oximetry; Exacerbation 


\section{Introduction}

Chronic obstructive pulmonary disease (COPD) is a highly prevalent chronic non communicable disease affecting 64 million people [1]. By 2030, COPD will become the third leading cause of death worldwide [2]. Total costs associated with this disease are estimated to be $€ 141$ billion in Europe [3]. Major contributors to the high economic and societal burden of COPD are exacerbations [4]. Exacerbations of COPD (defined as "a sustained worsening of the patient's condition, from the stable state and beyond normal day-to-day variations") [5] are typically stressful events in the natural history of the disease [6]. Low blood oxygen concentrations (hypoxemia) increase the risk of exacerbation, while exacerbations can also induce hypoxemia [7]. The risk of hypoxemia rises with increasing disease severity [6] and can lead to long-term adverse effects such as pulmonary hypertension and systematic inflammation, reducing quality of life in patients with COPD [7]. Long-term administration of oxygen decreases mortality in patients with severe resting hypoxemia [8] and is prescribed based on blood gas measurements [6].

Pulse oximetry is a non-invasive method to assess arterial blood oxygen concentrations that uses light absorption characteristics of hemoglobin [9]. Pulse oximeters produce a photoplethysmography (PPG) waveform, from which both peripheral oxygen saturation $\left(\mathrm{SpO}_{2}\right)$ and heart rate (HR) can be derived [10]. An $\mathrm{SpO}_{2}$ value below 92\% indicates blood gas measurements should be performed to assess the need for supplemental oxygen therapy [11]. Pulse oximetry is also used in telemonitoring applications $[12,13]$. These applications make use of information technology to monitor patients at a distance without a healthcare professional present at the monitoring site [14]. Telemonitored patients are able to consult healthcare professionals through video or phone calls (remote consultations) or send information gathered 
via questionnaires or physiological measurements (e.g. $\mathrm{HR}$ or $\mathrm{SpO}_{2}$ ) to healthcare professionals. In the case of management of COPD patients, this information can be used to detect exacerbations. Early detection of exacerbations can reduce hospitalizations and improve recovery and health-related quality of life [15]. Furthermore, it has been suggested that telemonitoring applications could even predict these events [12], which could lead to the prevention of detrimental hospitalizations [15]. Generally, telemonitoring applications are expected to become a key component in future healthcare [16].

Despite the frequent use of $\mathrm{SpO}_{2}$ measurements in COPD telemonitoring [13], no profound overview is available about these measurements. Therefore, this systematic review will evaluate the scientific literature on the application of $\mathrm{SpO}_{2}$ measurements in telemonitoring of patients with COPD.

\section{Methods}

\subsection{Search strategy}

The literature search was performed in PubMed and Web of Science on the $15^{\text {th }}$ of March 2017. The systematic search terms consisted of the following keywords: (mHealth OR "mobile health" OR tele(-)health OR tele(-)monitoring OR tele(-)medicine) AND (COPD OR "chronic obstructive pulmonary disease"). Search terms were not narrowed down to only $\mathrm{SpO}_{2}$ measurements to avoid exclusion of potentially valuable articles that did not mention $\mathrm{SpO}_{2}$ measurements in the abstract. Meta-analyses and reviews were excluded a priori. Article screening excluded duplicates, non-English articles, editorials, conference proceedings, articles without full-text availability and articles that were not applying $\mathrm{SpO}_{2}$ measurements in telemonitoring of patients with COPD. Additional articles were included based on reference list 
screenings from the articles retrieved via PubMed or Web of Science. Results were discussed with all co-authors and inventoried by the first author.

\subsection{Information extraction}

First, articles originating from the same study were grouped. If a project name was provided, this name was assigned to the corresponding study. Then, studies applying remote consultations were identified, as they have significantly different characteristics compared to telemonitoring implementations not requiring personal contact. Afterwards, participant numbers were extracted and in the case of a randomized controlled trial (RCT), participant numbers of both telemonitoring and usual care group were denoted. When possible, the distinction between COPD patients and other participants was made. In a next step, characteristics of the studies were extracted by identifying study duration, $\mathrm{SpO}_{2}$ measuring frequency and type of oximeter and associated telemonitoring system (used for storage and/or transmission of $\mathrm{SpO}_{2}$ data). Finally, information was extracted on the application and value of $\mathrm{SpO}_{2}$ measurements.

This review specifically aims to provide an overview of the use of $\mathrm{SpO}_{2}$ measurements in telemonitoring of COPD patients. However, most of the reviewed studies primarily focused on the results of whole telemonitoring systems, which depend on several technical and organizational factors of the whole telemonitoring set-up. Therefore, reporting on the overall results of the included studies is outside the scope of this systematic review.

\section{Results}

\subsection{Article selection}

The initial PubMed and Web of Science search retrieved 532 articles (Figure 1). After removal of duplicates $(n=169)$, non-English articles $(n=15)$, editorials $(n=13)$, conference proceedings $(n=12)$ and articles without full text availability $(n=11), 312$ articles remained. Full text 
screenings excluded articles that were not applying telemonitoring in COPD or performing $\mathrm{SpO}_{2}$ measurements $(n=243)$. Addition of articles from reference lists $(n=2)$ resulted in a final set of 71 articles.

\subsection{Study description}

Table 1 provides a description of the 71 included articles, originating from 50 distinct studies. The first article was published in 2004. Sixty-three of the 71 articles (89\%) have been published after 2010 .

The 50 included studies can be divided into studies with supervised measurements (during remote consultations; $n=6)$ and independent patient measurements $(n=44)$. Two types of remote consultations were performed: (i) short-term ( $\leq 14$ days) follow-up of patients released from the hospital after an exacerbation [17-23] (n=4); or (ii) long-term (12 months) remote monitoring [24-27] $(n=2)$. Regarding the 44 studies with independent patient measurements, most implemented telemonitoring for at least 2 months $(n=39)$ and almost two third of the studies lasted for at least 6 months $(\mathrm{n}=28)$. In almost half of the 50 included studies, less than 30 COPD patients were included for telemonitoring $(n=24)$. Very few studies reported on analyses of specific patient subpopulations (e.g. patients with and without oxygen therapy) and methods to characterize patients were not consistent. Therefore, no analyses of specific patient subpopulations could be made in this review.

\subsection{Measurements, oximeters and telemonitoring systems}

Forty-nine of the 50 included studies (98\%) used pulse oximeters for spot check measurements. Continuous measurements were only performed in the study of Faria et al. [28] (sampling frequency not specified). Frequency of spot check measurements ranged from 3 times in 5 hours to once weekly, with most of the studies measuring once daily $(n=38)$. Only three articles specified a protocol for performing the measurements. In Hurst et al. [29], participants performed 
$\mathrm{SpO}_{2}$ measurements each morning at the same time after 10 minutes of rest, on the same finger, but before taking medication. The highest obtained value during the measurement was retained. Jodar-Sanchez et al. [30] specified that measurements were taken 20 minutes after taking medication while seated, rested and on oxygen therapy. Shany et al. [31] had patients perform measurements after taking medications and while on oxygen therapy.

The pulse oximeter was specified in 26 of the 50 studies (Table 1). Almost half ( $\mathrm{n}=12$ ) of the 26 specified oximeters are manufactured by Nonin Medical ( 7 Nonin Onyx; 1 Nonin Avant; 4 unspecified Nonin). Nonin Onyx is a finger clip oximeter for spot check measurements; Nonin Avant is a wrist worn device with a linked finger clip able to perform continuous measurements. Considering all studies, the oximeters were used in combination with 15 different types of telemonitoring systems (Table 1).

\subsection{Application of $\mathrm{SpO}_{2}$ measurements}

In many studies, deviating $\mathrm{SpO}_{2}$ values were used to raise alerts $\left(\mathrm{SpO}_{2}\right.$ alerts $)$ that led to immediate action from healthcare professionals, ranging from phone calls to hospital admissions $(\mathrm{n}=34$; Table 1). Other studies developed methods to predict exacerbations through retrospective analysis of the measured $\mathrm{SpO}_{2}$ values $(\mathrm{n}=5)$. An additional retrospective analysis was also performed in three of the 34 studies that carried out immediate action [32-34]. The other eleven studies (i) did not specify the exact $\mathrm{SpO}_{2}$ use during remote consultations ( $\mathrm{n}=5$ ); or (ii) were set up for evaluation of a telemonitoring system and did not further use the measured $\mathrm{SpO}_{2}$ values $(n=6)$

\section{5 $\mathrm{SpO}_{2}$ alerts leading to immediate action}


The $\mathrm{SpO}_{2}$ alerts in the 34 studies that carried out immediate action were based on (i) abnormal values $(\mathrm{n}=10$; no further information was provided to describe what was considered to be an abnormal value), (ii) thresholds values ( $\mathrm{n}=23$; as discussed in next paragraph) or (iii) the output of an algorithm $(\mathrm{n}=1)$ (Table 1$)$. This algorithm used oximetry measurements in combination with questionnaire answers and spirometry measurements to predict exacerbation probability. High probabilities raised alerts, but the exact algorithm was not further specified [35].

Two types of thresholds can be distinguished: generic $(n=6)$ or individualized $(n=12)$. Five studies did not specify the type of threshold $(n=5)$. Generic thresholds were fixed on one value $(88 \%$ [36,37], $90 \%$ [24-26] or 92\% [38]) or on multiple values for a graded severity indication. Koff et al. [39] specified thresholds of $90 \%$ and $88 \%$, Ho et al. [40] on $92 \%$ and $90 \%$ and Colantonio et al. [41] made the distinction between breathing room air (thresholds of $92 \%$ and $90 \%$ ) and breathing $\mathrm{O}_{2}$ (thresholds of $93 \%, 90 \%$ and $80 \%$ ). Three studies that applied individual thresholds did not specify the method for determining the threshold values [42-44]. The other nine studies with individual thresholds based the threshold values on caregiver assessments or baseline measurements. Seven of these nine studies did not further clarify the exact determination of the threshold values. The other two studies denoted a quantitative method for determining the individualized threshold value: Segrelles Calvo et al. [45] set the threshold 3\% below the average of first 3 measuring days. The articles originating from the EDGE project $[34,46-48]$ defined the threshold value as the $95 \%$ percentile of the cumulative density function of the measured values of the first 6 weeks.

\subsection{Exacerbation prediction through retrospective analysis}


Eight articles developed methods to predict exacerbations through retrospective analysis of the measured $\mathrm{SpO}_{2}$ values: five originated from retrospective studies and three from studies that performed an additional retrospective analysis. Brown-Connolly used retrospective analysis to calculate the optimal generic threshold value by taking into account the accuracy of alerts to warn for hospitalizations, emergency admissions and home visits. A Receiver Operating Characteristics (ROC) analysis indicated $85-86 \%$ as the generic $\mathrm{SpO}_{2}$ threshold with both the highest sensitivity (0.62) and specificity (0.91) [32].

The other seven articles extracted features from daily measured $\mathrm{SpO}_{2}$ and used these features in addition to the measured $\mathrm{SpO}_{2}$ values to retrospectively develop methods to predict exacerbations. Mohktar et al. [33] calculated four features, based on the combination of daily measurements and the measurements of the previous 30 days: 30-day distribution mean and standard deviation, percentage change of daily measured values compared to distribution mean and the z-score of measured values compared to the 30-day distribution. The same features were calculated from five other variables (i.e. HR, blood pressure, lung function parameters, weight and temperature), after which they were used as input for a classification and regression tree algorithm to predict next-day risk of exacerbation. Shah et al. [34] calculated mean and linear fit gradient from 7-day periods of $\mathrm{SpO}_{2}, \mathrm{HR}$ and respiratory rate to be used as input for a logistic classifier to predict exacerbations. Jensen et al. [49] and Riis et al. [50] calculated features based on differing types (mean, standard deviation, skewness, kurtosis or linear regression between $\mathrm{SpO}_{2}$ and $\mathrm{HR}$ ) and durations (ranging between 5 and 30 days) and used them for prediction of exacerbation risk in the following 30 days or as input for a k-nearest neighbor classifier for prediction of exacerbation onset, respectively. Hurst et al. [29] calculated an oximetry score, based on the z-scores of $\mathrm{SpO}_{2}$ and $\mathrm{HR}$ from daily measurements compared to the distribution of 
measurements from the first 30 stable days. An oximetry-peak expiratory flow (PEF) score was calculated similarly by adding z-scores of PEF measurements to the equation. These scores were used to discriminate exacerbation onset from normal day-to-day symptom variations. Merone et al. [51] further specified this oximetry score by applying weights to the elements in the oximetry score formula and used this in a finite-state machine model for prediction of different types of adverse events (e.g. onset of exacerbation, hypoxemia or dyspnea). Lastly, Clarke et al. [52] decomposed time series of daily $\mathrm{SpO}_{2}$ measurements of 4 patients in a long-term trend, a shortterm trend and a residual signal. In one patient, the declining long-term trend clearly indicated the worsening health status of this patient. The residual signal outperformed the short-term trend for exacerbation predictions.

\subsection{Value of $\mathrm{SpO}_{2}$ measurements}

Most studies that carried out immediate action $(n=31)$ did not provide information about the correctness or effectiveness of the implemented $\mathrm{SpO}_{2}$ alerts and only considered general, longterm outcomes of the whole telemonitoring set-up (e.g. quality of life, morbidity or healthcare costs). Three studies that carried out immediate action and five studies with retrospective analyses did quantitatively evaluate the performance of stand-alone $\mathrm{SpO}_{2}$ measurement to detect or predict exacerbations (Table 2). Except for Hurst et al., alerts based on $\mathrm{SpO}_{2}$ measurements performed better than alerts based on other physiological variables, as can be seen in Table 2 by means of the higher AUC [32,34], the higher Cohen's kappa [33], because $\mathrm{SpO}_{2}$ was better able to differentiate between exacerbation days or usual days [53], or because $\mathrm{SpO}_{2}$ raised more accurate alerts $[44,45]$. The four articles that examined the ability to predict exacerbations of both stand-alone $\mathrm{SpO}_{2}$ measurements and of measurements of a combination of variables (including $\mathrm{SpO}_{2}$ ), all found an increase in performance when other physiological variables were 
added to the measurements of $\mathrm{SpO}_{2}$, indicated by the higher AUC $[29,34,49]$ or Cohen's kappa [33] (Table 2).

\section{Discussion}

This systematic review identified and evaluated the use of $\mathrm{SpO}_{2}$ measurements in telemonitoring of patients with COPD. In many studies, daily $\mathrm{SpO}_{2}$ measurements were performed for more than 6 months, indicating that long-term follow-up of COPD patients using daily $\mathrm{SpO}_{2}$ measurements is practically feasible. However, very few studies specified protocols for performing the measurements. Often the used oximeter was not mentioned. When specified, the oximeters from Nonin Medical were most frequently used. Overall, participant numbers were relatively low and the articles had no consistent method for characterizing the included patients. In many studies, deviating $\mathrm{SpO}_{2}$ values were used to raise alerts that led to immediate action from healthcare professionals (e.g. patient visits or hospital admissions). However, little information has been made available about the exact implementation of these alerts. Almost a third of the studies carrying out immediate action indicated that alerts were based on abnormal values, without further specifying when values were considered abnormal. Other alerts were based on exceeded threshold values, but these values were often not specified or only based on unspecified caregiver assessments. In addition, little attention was given to the optimal implementation of alerts. When generic threshold values were specified, they ranged between $88 \%$ and $92 \%$. However, the retrospective analyses of Brown-Connolly suggested lower values $(85-86 \%)$ as the optimal $\mathrm{SpO}_{2}$ threshold [32]. Moreover, COPD patients are generally considered a very heterogeneous population [88] with an overall decline in health status [6] and a variable baseline $\mathrm{SpO}_{2}$ [52]. Generic thresholds cannot take this variability into account. It can thus be assumed that individualized, time-dependent thresholds (i.e. personal thresholds that can change 
over time) will outperform generic thresholds [64]. Individualized thresholds were already implemented in some studies that carried out immediate action, but except for Segrelles Calvo et al. [45] and the articles originating from the EDGE project [34,46-48], no information was provided on how these thresholds were determined. All these elements illustrate the current lack of knowledge and transparency concerning alert implementations.

The studies with retrospective analyses focused more on alert optimizations. Brown-Connolly used retrospective analyses to calculate the optimal generic threshold value [32]. The other retrospective studies calculated additional features from daily measured $\mathrm{SpO}_{2}$ values and used these features to retrospectively predict exacerbations by applying thresholds to the feature values or by using the features as input for predictive algorithms. The calculated features were based on a combination of individual present day values and individual values from the last week or month, which allowed accounting for both individual differences and longer-term health status changes. This is important because general health status changes can lead to a different baseline $\mathrm{SpO}_{2}$ [52]. A decline in baseline $\mathrm{SpO}_{2}$, not related to exacerbations, could thus lead to a high amount of false alerts when the individual thresholds are not able to change accordingly. In addition, these features have the possibility to provide valuable information about the general, long-term health status of the monitored patients, as has been suggested by Clarke et al. [52]. Surprisingly, most of the calculated features were still based on simple, basic statistics such as mean, standard deviation or a linear fit gradient of past periods $[33,34,49,50]$. Only Clarke et al. [52] approached the daily measurements as a time series. The authors proposed a method to monitor both health status and the onset of exacerbations by using specific time-series analyses. However, their method is derived from data of only 4 patients and thus needs further validation. 
Little information was provided about the correctness and effectiveness of the $\mathrm{SpO}_{2}$ alerts in studies that performed immediate action, as these studies mostly only considered general, longterm outcomes of the whole telemonitoring set-up (e.g. quality of life, morbidity or healthcare costs). Nonetheless, the three articles that did evaluate the performance of $\mathrm{SpO}_{2}$-alerts quantitatively, indicate that these alerts could have the potential to detect or predict exacerbations: Martin-Lesende et al. [44] found that $\mathrm{SpO}_{2}$ alerts were mostly triggered in the five days prior to hospitalization, Segrelles Calvo et al. [45] found that most alerts for exacerbations were triggered by $\mathrm{SpO}_{2}$ and Burton et al. [53] indicated that $\mathrm{SpO}_{2}$ measurements could differentiate between exacerbation days and regular days. The retrospective analyses provide more information about the value of $\mathrm{SpO}_{2}$ measurements and indicate that stand-alone $\mathrm{SpO}_{2}$ measurements could have predictive power for exacerbations. Furthermore, the results in Table 2 suggest that exacerbation predictions based on stand-alone $\mathrm{SpO}_{2}$ measurements perform better than predictions based on measurements of other stand-alone physiological variables. Nevertheless, adding other physiological variables to $\mathrm{SpO}_{2}$ measurements can increase performance. A combination of $\mathrm{SpO}_{2}$ and $\mathrm{HR}$ might be especially valuable, having the additional advantage that both can be calculated from the same PPG signal as measured by oximeters [10]. Overall, this systematic review identified multiple shortcomings of the included articles concerning the $\mathrm{SpO}_{2}$ measurements and applications: measurement protocols and used oximeters were often not specified, participant numbers were generally low, little information was available about the implementation and performance of the alerts and alert implementations were not optimized. Therefore, no firm conclusions can be drawn on the real value of $\mathrm{SpO}_{2}$ measurements. Nevertheless, the few studies that assessed the value of $\mathrm{SpO}_{2}$ measurements indicated that these measurements could be valuable for exacerbation detections or predictions. 
Still, future research could optimize alerts based on regular $\mathrm{SpO}_{2}$ measurements by using individualized, time-dependent thresholds or predictive algorithms to account for individual differences and $\mathrm{SpO}_{2}$ baseline changes.

This systematic review identified only one study that performed continuous $\mathrm{SpO}_{2}$ measurements [28]. According to the authors of this review, future research should consider performing more continuous measurements of $\mathrm{SpO}_{2}$ instead of spot checks, possibly in combination with measurements of other variables that acutely influence $\mathrm{SpO}_{2}$ (e.g. physical activity and sleep [28]). This will provide a completer picture of the dynamics of $\mathrm{SpO}_{2}$, which can further lead to new features that can be used to determine individualized and time-dependent thresholds or predictive algorithms. Additionally, these measurements and features could be used to optimize oxygen therapy or training intensities in telerehabilitation programs [89]. In the study of Faria et al., patients treated according to conventional methods for long-term oxygen therapy carried out simultaneous continuous measurements of $\mathrm{SpO}_{2}$ and physical activity during activities of daily living, in combination with continuous $\mathrm{SpO}_{2}$ measurements during sleep [28]. Low $\mathrm{SpO}_{2}$ values were still found in continuous measurements during exercise, rest, and sleep, indicating that current long-term oxygen therapy guidelines (based on spot check measurements) could further be optimized by using continuous measurements. The dynamics of continuously measured $\mathrm{SpO}_{2}$ have so far only been examined during sleep in laboratory conditions, e.g. in obstructive sleep apnea [90] or apnea-hypopnea syndrome diagnosis [91]. In these studies, new insights were obtained by calculating a variety of features from continuously measured nocturnal $\mathrm{SpO}_{2}$.

Future research should assess the real value of continuous measurements through a formal comparison between spot check and continuous measurements, also considering differences in e.g. user acceptance or costs. Technological improvements can still increase the accuracy of 
continuous measurements taken with user friendly wearable devices (e.g. accurate measurements on the wrist, arm, or earlobe).

\section{Conclusions}

This review evaluates the scientific literature on the application of $\mathrm{SpO}_{2}$ measurements in telemonitoring of patients with COPD. The results indicate that long-term follow-up of COPD patients using daily spot check $\mathrm{SpO}_{2}$ measurements is practically feasible. However, very few studies specified protocols to perform $\mathrm{SpO}_{2}$ measurements. In many studies, deviating $\mathrm{SpO}_{2}$ values were used to raise alerts that led to immediate action from healthcare professionals. Other studies developed methods to predict exacerbations through retrospective analysis of the measured $\mathrm{SpO}_{2}$ values.

Little information was available about the exact implementation and performance of these alerts. Therefore, no firm conclusions can be drawn about the real value of $\mathrm{SpO}_{2}$ measurements. Nevertheless, the few studies that assessed the value of $\mathrm{SpO}_{2}$ measurements indicated that these measurements could be valuable for exacerbation detections or predictions.

Future research could optimize alerts based on daily measured $\mathrm{SpO}_{2}$ by using individualized, time-dependent thresholds or predictive algorithms to account for individual differences and $\mathrm{SpO}_{2}$ baseline changes. Additionally, the value of performing more continuous measurements should be examined, as these can make it possible to examine the $\mathrm{SpO}_{2}$ dynamics and account for factors that acutely influence the measurements (e.g. physical activity or sleep).

\section{Expert commentary}

The demographic shift towards an older population contributes to the increased burden of chronic non communicable diseases. These diseases are becoming more prominent causes of morbidity and mortality, and the treatment costs will keep increasing. New ways of managing 
chronic diseases are necessary to reach a sustainable healthcare system, including a shift in focus from treatment only towards prevention. Prevention does not only include keeping diseases from developing, it also includes preventive actions to gain control over the course of the disease. For the latter, telemonitoring can be used to timely indicate when preventive actions are required. Unfortunately, telemonitoring is not yet generally accepted because of a lack of compelling evidence of its beneficial long-term effects on healthcare costs, morbidity or mortality.

This lack of evidence is not surprising. Until now, very little attention has been directed towards the optimal exploitation of the gathered data, as has been confirmed by the results of this review. Standardizations, data science techniques and advancing technology can still boost performance of telemonitoring applications. Better performances will lead to higher acceptance, providing more opportunities to embed telemonitoring applications in daily practice, ultimately leading to a more sustainable healthcare system.

This review exposed some of the opportunities to increase performance of telemonitoring applications that measure oxygen saturation $\left(\mathrm{SpO}_{2}\right)$ in COPD patients. Telemonitoring of patients with COPD is mostly applied for detection of exacerbations to enable earlier and better treatment, but exacerbation detection has not been proven sufficiently accurate yet. A first step that must be taken to reach acceptable accuracies is the standardization of the $\mathrm{SpO}_{2}$ measurements. Very few articles provide information about a protocol to perform the measurements, which leads to unwanted variability in the measured values. Secondly, only articles with retrospective analyses explored some of the possibilities of data science techniques. This makes it impossible to assess the real added value of data science on longer-term outcomes such as healthcare costs or mortality. In addition, the applied techniques were mostly only based on simple, basic statistics such as means or standard deviations. More advanced data analysis 
techniques using time series analyses and predictive modelling should be applied in studies that can initiate immediate action to explore the real potential of telemonitoring in patients with COPD. Lastly, the advancing technology can make it possible to accurately measure $\mathrm{SpO}_{2}$ continuously instead of through spot checks only. This will allow exclusion of unwanted influences on the measurements (e.g. physical activity) and provide a completer picture of the dynamics of $\mathrm{SpO}_{2}$ during the day and/or night. Applying the appropriate analyses on these continuous measurements can give rise to a whole new set of individualized and time-dependent features that can further improve the performance of telemonitoring applications. Only when all these opportunities are thoroughly explored, the real value of telemonitoring $\mathrm{SpO}_{2}$ in $\mathrm{COPD}$ patients can be assessed.

\section{Five-year view}

No firm conclusions can be drawn about the real value of $\mathrm{SpO}_{2}$ measurements in telemonitoring applications because many improvements that could lead to better performances are still underexplored. Therefore, the focus of future research will be increasingly on incorporating data science techniques in telemonitoring applications for COPD patients. The use of more complex predictive algorithms will improve exacerbation predictions and the constant technological advancements will make it possible to use wearables to continuously and accurately measure $\mathrm{SpO}_{2}$ without interfering in the patient's daily life. Using appropriate data science techniques on these continuous $\mathrm{SpO}_{2}$ measurements can further boost the performance of telemonitoring applications, which will ultimately lead to a higher acceptance of telemonitoring applications in daily practice.

Figure1:Article selection resulted in 71 included articles 
Database search $n=532$

Exclude duplicates $(n=169)$

After duplicate removal $n=363$

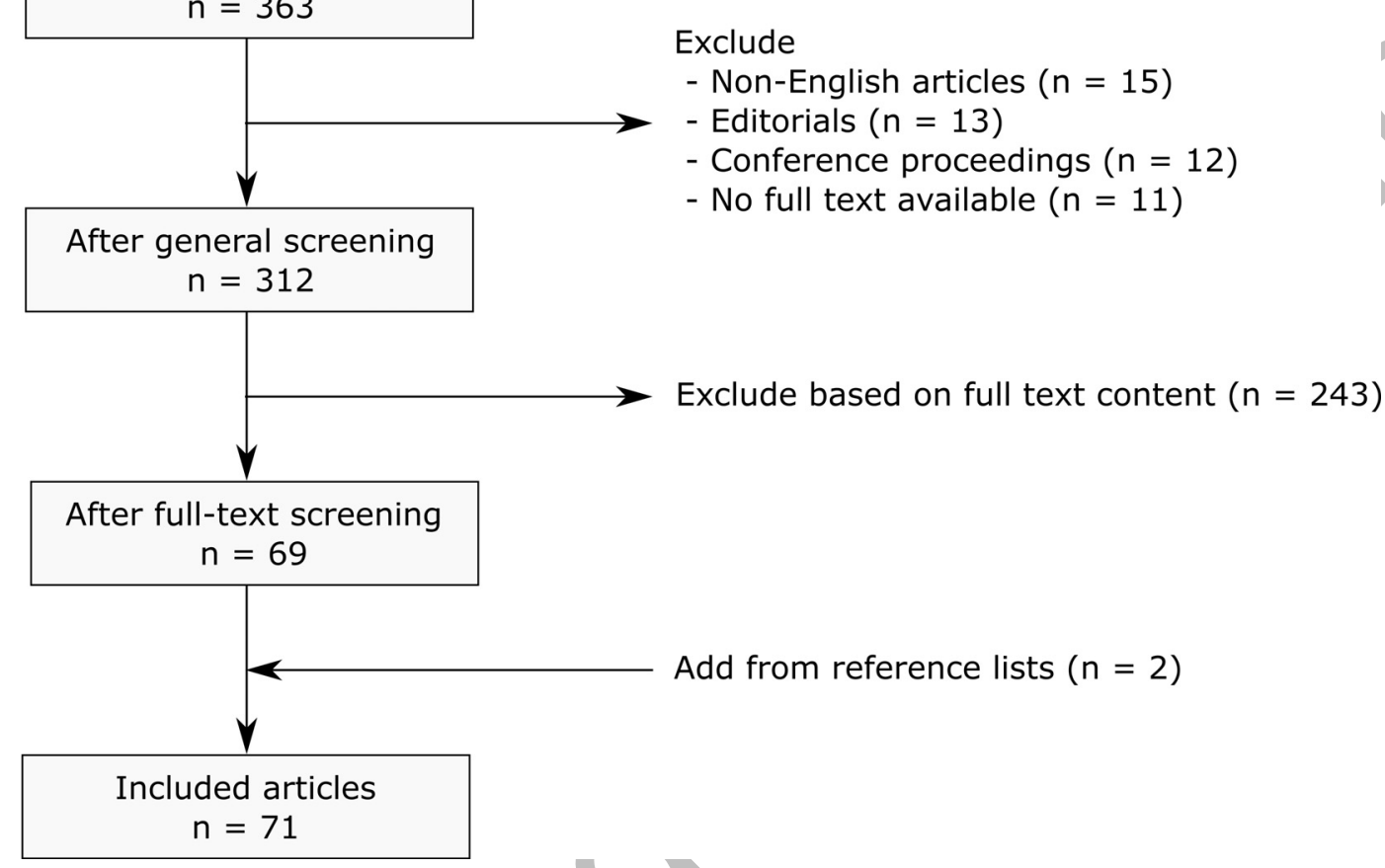


Table 1 Overview of the 71 included articles, based on 50 individual studies ${ }^{1}$

\begin{tabular}{|c|c|c|c|c|c|c|c|c|c|c|c|}
\hline Author & $\begin{array}{c}\text { Yea } \\
r\end{array}$ & $\begin{array}{c}\text { Project } \\
\text { name }\end{array}$ & \multicolumn{2}{|c|}{$\begin{array}{c}\text { Participant } \\
\text { s (n) }\end{array}$} & \multicolumn{2}{|c|}{$\begin{array}{l}\text { FEV1 } \\
\text { \%pred } \\
\text { (mean }\end{array}$} & \multirow{2}{*}{$\begin{array}{c}\begin{array}{c}\text { Study } \\
\text { duratio } \\
n\end{array} \\
176 \pm \\
12 \\
6 \text { or } 12\end{array}$} & \multirow{2}{*}{$\begin{array}{c}\begin{array}{c}\text { Measurin } \\
g\end{array} \\
\text { frequenc }\end{array}$} & \multirow{2}{*}{$\begin{array}{c}\begin{array}{c}\text { Oximeter } \\
\text { type }\end{array} \\
\text { Nonin } \\
\text { Onyx or } \\
2500\end{array}$} & \multirow{2}{*}{ 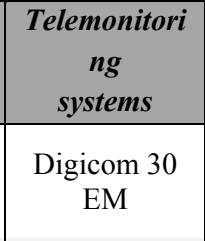 } & \multirow{2}{*}{$\begin{array}{c}\mathrm{SpO}_{2} \\
\text { applicatio } \\
\boldsymbol{n} \\
\text { Alert: } \\
\text { Threshold } \\
\text { - Generic }\end{array}$} \\
\hline $\begin{array}{l}\text { Vitacca } \\
\text { Vitacca } \\
\text { Vitacca }\end{array}$ & $\begin{array}{l}200 \\
200 \\
201\end{array}$ & / & $\begin{array}{l}17^{*} \\
57^{*} \\
181\end{array}$ & $44^{*}$ & $\begin{array}{c}33 \\
39 \\
/\end{array}$ & 34 & & & & & \\
\hline $\begin{array}{l}\text { Koizumi } \\
\text { [27] }\end{array}$ & $\begin{array}{c}200 \\
5\end{array}$ & / & 2 & & / & & $\begin{array}{c}12 \\
\text { months }\end{array}$ & 1x/week & $\begin{array}{l}\text { Nihon } \\
\text { Kohden }\end{array}$ & $\begin{array}{l}\text { Nihon } \\
\text { Kohden }\end{array}$ & $\begin{array}{l}\text { No alert: } \\
\text { Use not }\end{array}$ \\
\hline $\begin{array}{c}\text { Schou [18] } \\
\text { Schou } \\
\text { Emme }\end{array}$ & $\begin{array}{l}201 \\
201 \\
201 \\
201\end{array}$ & $\begin{array}{c}\text { Virtual } \\
\text { Hospital } \\
\text { Trial }\end{array}$ & $\begin{array}{l}22 \\
22 \\
25 \\
28\end{array}$ & $\begin{array}{l}22 \\
22 \\
25 \\
29\end{array}$ & $\begin{array}{c}39 \\
39 \\
31 \\
/\end{array}$ & $\begin{array}{c}44 \\
44 \\
29 \\
/\end{array}$ & $\begin{array}{c}2-8 \\
2-8 \\
1-11 \\
/\end{array}$ & $\begin{array}{l}\text { Once } \\
\text { daily }\end{array}$ & / & $\begin{array}{c}\text { Touch screen } \\
\text { PC }\end{array}$ & $\begin{array}{l}\text { No alert: } \\
\text { Use not } \\
\text { specified } \\
\text { (RC) }\end{array}$ \\
\hline $\begin{array}{c}\text { Sorknaes } \\
{[23]}\end{array}$ & $\begin{array}{c}201 \\
3\end{array}$ & I & 132 & 134 & $\begin{array}{c}33 \\
\pm\end{array}$ & $\begin{array}{l}37 \\
\pm\end{array}$ & $\begin{array}{c}5-9 \\
\text { days }\end{array}$ & $\begin{array}{l}\text { Once } \\
\text { daily }\end{array}$ & $\begin{array}{c}\text { MIR } \\
\text { Spirotel }\end{array}$ & / & $\begin{array}{l}\text { No alert: } \\
\text { Use not }\end{array}$ \\
\hline $\begin{array}{c}\text { Gottlieb } \\
{[21]}\end{array}$ & $\begin{array}{c}201 \\
4\end{array}$ & TELEKOL & 72 & & / & & 14 days & $\begin{array}{l}\text { Once } \\
\text { daily }\end{array}$ & / & / & $\begin{array}{l}\text { No alert: } \\
\text { Use not }\end{array}$ \\
\hline Saleh [22] & $\begin{array}{c}201 \\
4\end{array}$ & / & 99 & & / & & 14 days & $\begin{array}{l}\text { Once } \\
\text { daily }\end{array}$ & / & Computer & $\begin{array}{l}\text { No alert: } \\
\text { Use not }\end{array}$ \\
\hline $\begin{array}{c}\text { Venter } \\
{[54]}\end{array}$ & $\begin{array}{c}201 \\
2\end{array}$ & / & $\begin{array}{c}10 * \\
*\end{array}$ & $\begin{array}{c}10 * \\
*\end{array}$ & / & & $\begin{array}{c}12 \\
\text { months }\end{array}$ & & $\begin{array}{l}\text { TMC } \\
\text { Health }\end{array}$ & $\begin{array}{l}\text { TMC Health } \\
\text { Monitor }\end{array}$ & $\begin{array}{c}\text { Alert: } \\
\text { Abnormal }\end{array}$ \\
\hline $\begin{array}{l}\text { Jensen } \\
{[49]}\end{array}$ & $\begin{array}{c}201 \\
2\end{array}$ & TELEKAT & 57 & & / & / & $\begin{array}{c}4 \\
\text { months }\end{array}$ & $\begin{array}{c}\text { Prescribe } \\
\text { d }\end{array}$ & $\begin{array}{l}\text { Nonin } \\
\text { Onyx }\end{array}$ & l & $\begin{array}{c}\text { Retrospect } \\
\text { ive }\end{array}$ \\
\hline $\begin{array}{l}\text { Lilholt } \\
\text { Lilholt } \\
\text { Haesum }\end{array}$ & $\begin{array}{l}201 \\
201 \\
201 \\
201\end{array}$ & $\begin{array}{c}\text { Danish } \\
\text { TeleCare } \\
\text { North Trial }\end{array}$ & $\begin{array}{c}60 \\
60 \\
60 \\
263\end{array}$ & $\begin{array}{c}56 \\
290\end{array}$ & $\begin{array}{c}/ \\
/ \\
48 \\
49\end{array}$ & $\begin{array}{c}/ \\
/ \\
50 \\
48\end{array}$ & $\begin{array}{c}2 \\
2 \\
2 \\
12\end{array}$ & $\begin{array}{c}\text { First } 2 \\
\text { weeks: } \\
\text { 1x/day } \\
\text { Afterwar }\end{array}$ & $\begin{array}{l}\text { Nonin } \\
\text { Onyx }\end{array}$ & $\begin{array}{c}\text { Samsung } \\
\text { Galaxy Tab } \\
2\end{array}$ & $\begin{array}{c}\text { Alert: } \\
\text { Abnormal } \\
\text { values }\end{array}$ \\
\hline $\begin{array}{l}\text { Achelrod } \\
{[35]}\end{array}$ & $\begin{array}{c}201 \\
6\end{array}$ & / & 651 & $\begin{array}{c}704 \\
7\end{array}$ & / & / & $\begin{array}{c}12 \\
\text { months }\end{array}$ & 2x/week & I & I & $\begin{array}{c}\text { Alert: } \\
\text { Algorithm }\end{array}$ \\
\hline $\begin{array}{c}\text { Colantoni } \\
\text { o [41] }\end{array}$ & $\begin{array}{c}201 \\
5\end{array}$ & / & 26 & & $\begin{array}{c}38 \\
\pm\end{array}$ & & $\begin{array}{c}115 \pm \\
40 \text { days }\end{array}$ & 3x/week & / & l & $\begin{array}{c}\text { Alert: } \\
\text { Threshold }\end{array}$ \\
\hline Finkelstei & $\begin{array}{l}200 \\
200\end{array}$ & $\begin{array}{c}\text { TeleHomeC } \\
\text { are }\end{array}$ & $\begin{array}{l}11^{*} \\
11^{*}\end{array}$ & $\begin{array}{l}14 * \\
14 *\end{array}$ & $\begin{array}{l}1 \\
1\end{array}$ & $\begin{array}{l}1 \\
1\end{array}$ & $\begin{array}{l}1 \\
1\end{array}$ & $\begin{array}{l}\text { Once } \\
\text { daily }\end{array}$ & Nonin & l & $\begin{array}{c}\text { Alert: } \\
\text { Threshold }\end{array}$ \\
\hline $\begin{array}{l}\text { Lamothe } \\
\text { [43] }\end{array}$ & $\begin{array}{c}200 \\
6\end{array}$ & / & $82 *$ & & / & & $\begin{array}{l}6-243 \\
\text { days }\end{array}$ & $\begin{array}{l}\text { Once } \\
\text { daily }\end{array}$ & $\begin{array}{c}\text { Honeywe } \\
11\end{array}$ & $\begin{array}{c}\text { Honeywell } \\
\text { HomMed }\end{array}$ & $\begin{array}{c}\text { Alert: } \\
\text { Threshold }\end{array}$ \\
\hline $\begin{array}{c}\text { Smaradotti } \\
\mathrm{r}[61]\end{array}$ & $\begin{array}{c}201 \\
5\end{array}$ & l & 6 & & / & & 7 days & $\begin{array}{l}\text { Once } \\
\text { daily }\end{array}$ & $\begin{array}{l}\text { Nonin } \\
\text { Onyx }\end{array}$ & Tablet & $\begin{array}{l}\text { No alert: } \\
\text { System }\end{array}$ \\
\hline $\begin{array}{c}\text { van der } \\
\text { Heijden } \\
{[62]} \\
\end{array}$ & $\begin{array}{c}201 \\
3\end{array}$ & / & 5 & & / & & 9 days & $\begin{array}{l}\text { Once } \\
\text { daily }\end{array}$ & Nonin & $\begin{array}{l}\text { Smartphone } \\
\text { \& Mobi }\end{array}$ & $\begin{array}{l}\text { No alert: } \\
\text { System } \\
\text { evaluation }\end{array}$ \\
\hline Author & $\begin{array}{c}Y e a \\
r\end{array}$ & $\begin{array}{c}\text { Project } \\
\text { name }\end{array}$ & $\begin{array}{r}\text { Partici } \\
\text { s (n }\end{array}$ & & $\begin{array}{c}F E) \\
\% p r \\
(m e a \\
\end{array}$ & & $\begin{array}{c}\text { Study } \\
\text { duratio } \\
n\end{array}$ & $\begin{array}{c}\text { Measuri } \\
\text { ng } \\
\text { frequenc }\end{array}$ & $\begin{array}{l}\text { Oximeter } \\
\text { type }\end{array}$ & $\begin{array}{c}\text { Telemonitori } \\
\text { ng } \\
\text { systems } \\
\end{array}$ & $\begin{array}{c}\mathrm{SpO}_{2} \\
\text { application }\end{array}$ \\
\hline $\begin{array}{c}\text { Cardozo } \\
\lceil 63\rceil\end{array}$ & $\begin{array}{c}201 \\
0\end{array}$ & I & $\begin{array}{c}119 \\
*\end{array}$ & & / & & 60 days & $\begin{array}{l}\text { Once } \\
\text { daily }\end{array}$ & / & $\begin{array}{l}\text { Bosch } \\
\text { Health }\end{array}$ & $\begin{array}{c}\text { Alert: } \\
\text { Abnormal }\end{array}$ \\
\hline $\begin{array}{c}\text { Hamad } \\
{[64]}\end{array}$ & $\begin{array}{c}201 \\
6\end{array}$ & l & 183 & & / & & $\begin{array}{l}80.7 \\
\text { days }\end{array}$ & $\begin{array}{l}\text { Once } \\
\text { daily }\end{array}$ & / & Docobo & $\begin{array}{c}\text { Alert: } \\
\text { Threshold - }\end{array}$ \\
\hline Hurst [29] & $\begin{array}{c}201 \\
0\end{array}$ & I & 31 & & $\begin{array}{c}46 \\
\pm\end{array}$ & & 87 days & $\begin{array}{l}\text { Once } \\
\text { daily }\end{array}$ & $\begin{array}{l}\text { Nonin } \\
\text { Onyx }\end{array}$ & l & $\begin{array}{l}\text { Retrospecti } \\
\text { ve analysis }\end{array}$ \\
\hline Davis [65] & $\begin{array}{c}201 \\
5\end{array}$ & l & $58 *$ & $\begin{array}{c}174 \\
*\end{array}$ & / & & 90 days & $\begin{array}{l}\text { Once } \\
\text { daily }\end{array}$ & / & Cardiocom & $\begin{array}{c}\text { Alert: } \\
\text { Abnormal }\end{array}$ \\
\hline Ho [40] & $\begin{array}{c}201 \\
6\end{array}$ & / & 53 & 53 & $\begin{array}{c}62 \\
\pm\end{array}$ & $\begin{array}{c}62 \\
\pm\end{array}$ & $\begin{array}{c}2 \\
\text { months }\end{array}$ & $\begin{array}{l}\text { Once } \\
\text { daily }\end{array}$ & / & / & $\begin{array}{c}\text { Alert: } \\
\text { Threshold }\end{array}$ \\
\hline Koff [39] & $\begin{array}{c}200 \\
9\end{array}$ & / & 20 & 20 & $\begin{array}{c}34 \\
\pm\end{array}$ & $\begin{array}{c}31 \\
\pm\end{array}$ & $\begin{array}{c}3 \\
\text { months }\end{array}$ & $\begin{array}{l}\text { Once } \\
\text { daily }\end{array}$ & $\begin{array}{c}\text { GE } \\
\text { Healthca }\end{array}$ & $\begin{array}{l}\text { Bosch } \\
\text { Health }\end{array}$ & $\begin{array}{c}\text { Alert: } \\
\text { Threshold - }\end{array}$ \\
\hline $\begin{array}{l}\text { Gellis } \\
\text { Gellis }\end{array}$ & $\begin{array}{l}201 \\
201\end{array}$ & $\begin{array}{l}\text { I-TEAM or } \\
\text { TELE- }\end{array}$ & $\begin{array}{l}11 * \\
11 *\end{array}$ & $\begin{array}{l}15^{*} \\
15^{*}\end{array}$ & $\begin{array}{l}\text { / } \\
\text { / }\end{array}$ & $\begin{array}{l}1 \\
1\end{array}$ & $\begin{array}{l}3 \\
3\end{array}$ & $\begin{array}{l}\text { Once } \\
\text { daily }\end{array}$ & $\begin{array}{c}\text { Honeywe } \\
11\end{array}$ & $\begin{array}{c}\text { Honeywell } \\
\text { HomMed }\end{array}$ & $\begin{array}{c}\text { Alert: } \\
\text { Abnormal }\end{array}$ \\
\hline
\end{tabular}




\begin{tabular}{|c|c|c|c|c|c|c|c|c|c|c|c|}
\hline $\begin{array}{l}\text { Jodar- } \\
\text { Jodar- }\end{array}$ & $\begin{array}{l}201 \\
201\end{array}$ & I & $\begin{array}{l}24 \\
24\end{array}$ & $\begin{array}{l}21 \\
21\end{array}$ & $\begin{array}{c}37 \\
/\end{array}$ & $\begin{array}{c}38 \\
/\end{array}$ & $\begin{array}{l}4 \\
4\end{array}$ & $\begin{array}{l}\text { Once } \\
\text { daily }\end{array}$ & $\begin{array}{c}\text { MIR } \\
\text { Spirotel }\end{array}$ & $\begin{array}{c}\text { Aerotel } \\
\text { TeleModem }\end{array}$ & $\begin{array}{c}\text { Alert: } \\
\text { Threshold - }\end{array}$ \\
\hline $\begin{array}{r}\text { Ure [69] } \\
\text { Burton }\end{array}$ & $\begin{array}{l}201 \\
201\end{array}$ & TELESCOT & $\begin{array}{l}20 \\
19\end{array}$ & & $\begin{array}{c}45 \\
/\end{array}$ & & $\begin{aligned} & 6 \\
> & 200\end{aligned}$ & $\begin{array}{l}\text { Once } \\
\text { daily }\end{array}$ & I & $\begin{array}{c}\text { Touch screen } \\
\text { PC }\end{array}$ & $\begin{array}{l}\text { No alert: } \\
\text { System }\end{array}$ \\
\hline $\begin{array}{c}\text { Teijeiro } \\
{[70]}\end{array}$ & $\begin{array}{c}201 \\
3\end{array}$ & / & 18 & & / & & $\begin{array}{c}6 \\
\text { months }\end{array}$ & $\begin{array}{l}\text { Once } \\
\text { daily }\end{array}$ & / & Smartphone & $\begin{array}{l}\text { No alert: } \\
\text { System }\end{array}$ \\
\hline $\begin{array}{l}\text { De San } \\
\text { Miguel }\end{array}$ & $\begin{array}{c}201 \\
3\end{array}$ & / & 36 & 35 & / & I & $\begin{array}{c}6 \\
\text { months }\end{array}$ & $\begin{array}{l}\text { Once } \\
\text { daily }\end{array}$ & I & Docobo & $\begin{array}{c}\text { Alert: } \\
\text { Threshold - }\end{array}$ \\
\hline Ding [72] & $\begin{array}{c}201 \\
4\end{array}$ & / & 10 & & $\begin{array}{c}51 \\
\pm\end{array}$ & & $\begin{array}{c}6 \\
\text { months }\end{array}$ & $\begin{array}{l}\text { Once } \\
\text { daily }\end{array}$ & I & Smartphone & $\begin{array}{l}\text { No alert: } \\
\text { System }\end{array}$ \\
\hline $\begin{array}{l}\text { Segrelles } \\
\text { Calvo }\end{array}$ & $\begin{array}{c}201 \\
4\end{array}$ & PROMETE & 29 & 30 & I & I & $\begin{array}{c}6 \\
\text { months }\end{array}$ & $\begin{array}{l}\text { Once } \\
\text { daily }\end{array}$ & $\begin{array}{c}\text { MIR } \\
\text { Spirotel }\end{array}$ & $\begin{array}{c}\text { Aerotel } \\
\text { TeleModem }\end{array}$ & $\begin{array}{c}\text { Alert: } \\
\text { Threshold - }\end{array}$ \\
\hline $\begin{array}{c}\mathrm{MacNab} \\
{[38]}\end{array}$ & $\begin{array}{c}201 \\
5\end{array}$ & I & 51 & & I & & $\begin{array}{c}6 \\
\text { months }\end{array}$ & $\begin{array}{l}\text { Once } \\
\text { daily }\end{array}$ & / & / & $\begin{array}{c}\text { Alert: } \\
\text { Threshold - }\end{array}$ \\
\hline $\begin{array}{c}\text { Kenealy } \\
\text { [73] }\end{array}$ & $\begin{array}{c}201 \\
5\end{array}$ & I & $\begin{array}{c}98 * \\
*\end{array}$ & $\begin{array}{c}73 * \\
*\end{array}$ & l & & $\begin{array}{c}6 \\
\text { months }\end{array}$ & $\begin{array}{l}\text { Once } \\
\text { daily }\end{array}$ & / & Docobo & $\begin{array}{c}\text { Alert: } \\
\text { Threshold - }\end{array}$ \\
\hline $\begin{array}{c}\text { McDowel } \\
1[74]\end{array}$ & $\begin{array}{c}201 \\
5\end{array}$ & / & 55 & 55 & $\begin{array}{l}46 \\
\pm\end{array}$ & $\begin{array}{l}43 \\
\pm\end{array}$ & $\begin{array}{c}6 \\
\text { months }\end{array}$ & $\begin{array}{l}\text { Once } \\
\text { daily }\end{array}$ & $\begin{array}{c}\text { Honeywe } \\
11\end{array}$ & $\begin{array}{c}\text { Honeywell } \\
\text { HomMed }\end{array}$ & $\begin{array}{c}\text { Alert: } \\
\text { Threshold - }\end{array}$ \\
\hline $\begin{array}{c}\text { Chatwin } \\
\text { [42] }\end{array}$ & $\begin{array}{c}201 \\
6\end{array}$ & TeleCRAFT & $19 *$ & $20 *$ & I & & $\begin{array}{c}6 \\
\text { months }\end{array}$ & $\begin{array}{l}\text { Once } \\
\text { daily }\end{array}$ & / & $\begin{array}{l}\text { Philips } \\
\text { MOTIVA }\end{array}$ & $\begin{array}{c}\text { Alert: } \\
\text { Threshold - }\end{array}$ \\
\hline $\begin{array}{l}\text { Brown- } \\
\text { Connolly }\end{array}$ & $\begin{array}{c}201 \\
4\end{array}$ & I & 34 & & / & & $\begin{array}{l}>6 \\
\text { months }\end{array}$ & $\begin{array}{l}\text { Once } \\
\text { daily }\end{array}$ & I & I & $\begin{array}{c}\text { Alert: } \\
\text { Threshold - }\end{array}$ \\
\hline $\begin{array}{c}\text { Zamith } \\
{[75]}\end{array}$ & $\begin{array}{c}200 \\
9\end{array}$ & REALITY & $21 *$ & & I & & $\begin{array}{c}9 \\
\text { months }\end{array}$ & $\begin{array}{l}\text { Once } \\
\text { daily }\end{array}$ & $\begin{array}{l}\text { Smiths } \\
\text { Medical }\end{array}$ & Docobo & $\begin{array}{l}\text { No alert: } \\
\text { System }\end{array}$ \\
\hline $\begin{array}{c}\text { Steventon } \\
{[76]}\end{array}$ & $\begin{array}{c}201 \\
6\end{array}$ & / & $\begin{array}{c}467 \\
*\end{array}$ & $\begin{array}{c}446 \\
*\end{array}$ & I & 1 & $\begin{array}{c}10.4 \\
\text { months }\end{array}$ & $\begin{array}{l}\text { Once } \\
\text { daily }\end{array}$ & / & $\begin{array}{c}\text { Tunstall } \\
\text { MyMedic }\end{array}$ & $\begin{array}{c}\text { Alert: } \\
\text { Threshold - }\end{array}$ \\
\hline Author & $\begin{array}{c}\text { Yea } \\
r\end{array}$ & $\begin{array}{c}\text { Project } \\
\text { name }\end{array}$ & \multicolumn{2}{|c|}{$\begin{array}{c}\text { Participant } \\
s(n)\end{array}$} & \multicolumn{2}{|c|}{$\begin{array}{c}\text { FEVI } \\
\text { \%pred } \\
\text { (mean } \pm\end{array}$} & $\begin{array}{c}\text { Study } \\
\text { duratio } \\
n \\
\end{array}$ & $\begin{array}{l}\text { Measuri } \\
\text { ng } \\
\text { frequenc }\end{array}$ & $\begin{array}{c}\text { Oximeter } \\
\text { type }\end{array}$ & $\begin{array}{c}\text { Telemonitori } \\
\text { ng } \\
\text { systems } \\
\end{array}$ & $\begin{array}{c}\mathrm{SpO}_{2} \\
\text { application }\end{array}$ \\
\hline $\begin{array}{c}\text { Clarke } \\
{[52]}\end{array}$ & $\begin{array}{c}201 \\
6\end{array}$ & / & 6 & & 1 & & $\begin{array}{c}347.4 \\
\text { days }\end{array}$ & $\begin{array}{l}\text { Once } \\
\text { daily }\end{array}$ & / & I & $\begin{array}{l}\text { Retrospecti } \\
\text { ve analysis }\end{array}$ \\
\hline $\begin{array}{l}\text { Martin- } \\
\text { Lesende }\end{array}$ & $\begin{array}{c}201 \\
3\end{array}$ & TELBIL & $\begin{array}{c}28 * \\
*\end{array}$ & $\begin{array}{c}30 * \\
*\end{array}$ & / & $\gamma$ & $\begin{array}{c}12 \\
\text { months }\end{array}$ & $\begin{array}{l}\text { Once } \\
\text { daily }\end{array}$ & / & PDA & $\begin{array}{c}\text { Alert: } \\
\text { Threshold - }\end{array}$ \\
\hline Antoniade & $\begin{array}{l}201 \\
201\end{array}$ & 1 & $\begin{array}{l}22 \\
21\end{array}$ & 22 & $\begin{array}{l}1 \\
34\end{array}$ & I & $\begin{array}{l}12 \\
12\end{array}$ & $\begin{array}{l}\text { Once } \\
\text { daily }\end{array}$ & $\begin{array}{l}\text { TMC } \\
\text { Health }\end{array}$ & $\begin{array}{l}\text { TMC Health } \\
\text { Monitor }\end{array}$ & $\begin{array}{c}\text { Alert: } \\
\text { Abnormal }\end{array}$ \\
\hline Pinnock & $\begin{array}{l}201 \\
201\end{array}$ & I & $\begin{array}{l}128 \\
128\end{array}$ & $\begin{array}{l}128 \\
128\end{array}$ & $\begin{array}{l}44 \\
44\end{array}$ & $\begin{array}{l}40 \\
40\end{array}$ & $\begin{array}{l}12 \\
12\end{array}$ & $\begin{array}{l}\text { Once } \\
\text { daily }\end{array}$ & I & $\begin{array}{c}\text { Touch screen } \\
\text { PC }\end{array}$ & $\begin{array}{c}\text { Alert: } \\
\text { Threshold - }\end{array}$ \\
\hline Steventon & $\begin{array}{l}201 \\
201 \\
201 \\
201\end{array}$ & $\begin{array}{c}\text { Whole } \\
\text { Systems } \\
\text { Demonstrat } \\
\text { or }\end{array}$ & $\begin{array}{l}739 \\
549 \\
334 \\
334\end{array}$ & $\begin{array}{l}786 \\
520 \\
244 \\
244\end{array}$ & $\begin{array}{l}1 \\
1 \\
1 \\
1\end{array}$ & $\begin{array}{l}1 \\
1 \\
1 \\
1\end{array}$ & $\begin{array}{c}12 \\
12 \\
12 \\
4 \text { or } 12\end{array}$ & $\begin{array}{l}\text { Once } \\
\text { daily }\end{array}$ & I & / & $\begin{array}{c}\text { Alert: } \\
\text { Threshold - } \\
\text { Individual }\end{array}$ \\
\hline $\begin{array}{c}\text { Vianello } \\
\text { [84] }\end{array}$ & $\begin{array}{c}201 \\
6\end{array}$ & 1 & 230 & 104 & 1 & 1 & $\begin{array}{c}12 \\
\text { months }\end{array}$ & $\begin{array}{l}\text { Once } \\
\text { daily }\end{array}$ & MCWC & I & $\begin{array}{c}\text { Alert: } \\
\text { Abnormal }\end{array}$ \\
\hline $\begin{array}{c}\text { Shany } \\
{[31]}\end{array}$ & $\begin{array}{c}201 \\
6\end{array}$ & 1 & 21 & 21 & $\begin{array}{c}40 \\
\pm\end{array}$ & $\begin{array}{l}32 \\
\pm\end{array}$ & $\begin{array}{c}12 \\
\text { months }\end{array}$ & $\begin{array}{l}\text { Once } \\
\text { daily }\end{array}$ & $\begin{array}{l}\text { TMC } \\
\text { Health }\end{array}$ & $\begin{array}{l}\text { TMC Health } \\
\text { Monitor }\end{array}$ & $\begin{array}{c}\text { Alert: } \\
\text { Threshold - }\end{array}$ \\
\hline $\begin{array}{c}\text { Velardo } \\
\text { Shah }\end{array}$ & $\begin{array}{l}201 \\
201 \\
201 \\
201\end{array}$ & $\begin{array}{l}\text { EDGE } \\
\text { project }\end{array}$ & $\begin{array}{c}19 \\
18 \\
110 \\
100\end{array}$ & & $\begin{array}{l}1 \\
1 \\
1 \\
1\end{array}$ & $\begin{array}{l}1 \\
1 \\
1 \\
1\end{array}$ & $\begin{array}{c}6 \\
6 \\
12 \\
12\end{array}$ & $\begin{array}{l}\text { Once } \\
\text { daily }\end{array}$ & $\begin{array}{l}\text { Nonin } \\
\text { Onyx }\end{array}$ & $\begin{array}{c}\text { Samsung } \\
\text { Galaxy Tab } \\
2\end{array}$ & $\begin{array}{c}\text { Alert: } \\
\text { Threshold - } \\
\text { Individual }\end{array}$ \\
\hline Riis [50] & $\begin{array}{c}201 \\
6\end{array}$ & I & 108 & & 1 & & 2 years & $\begin{array}{l}\text { Once } \\
\text { daily }\end{array}$ & $\begin{array}{l}\text { Nonin } \\
\text { Onyx }\end{array}$ & $\begin{array}{c}\text { Tunstall } \\
\text { RTX } 3371\end{array}$ & $\begin{array}{l}\text { Retrospecti } \\
\text { ve analysis }\end{array}$ \\
\hline $\begin{array}{c}\text { Esteban } \\
{[85]}\end{array}$ & $\begin{array}{c}201 \\
6\end{array}$ & telEPOC & 119 & 75 & $\begin{array}{l}46 \\
\pm\end{array}$ & $\begin{array}{l}45 \\
\pm\end{array}$ & 2 years & $\begin{array}{l}\text { Once } \\
\text { daily }\end{array}$ & / & Smartphone & $\begin{array}{c}\text { Alert: } \\
\text { Threshold - }\end{array}$ \\
\hline $\begin{array}{l}\text { Lewis } \\
\text { Lewis }\end{array}$ & $\begin{array}{l}201 \\
201\end{array}$ & 1 & $\begin{array}{l}20 \\
20\end{array}$ & $\begin{array}{l}20 \\
20\end{array}$ & $\begin{array}{l}38 \\
38\end{array}$ & $\begin{array}{l}40 \\
40\end{array}$ & $\begin{array}{l}6 \\
6\end{array}$ & $2 x /$ day & Nonin & Docobo & $\begin{array}{c}\text { Alert: } \\
\text { Threshold - }\end{array}$ \\
\hline Chau [86] & $\begin{array}{c}201 \\
2\end{array}$ & / & 22 & 18 & $\begin{array}{l}38 \\
\pm\end{array}$ & $\begin{array}{l}38 \\
\pm\end{array}$ & $\begin{array}{c}2 \\
\text { months }\end{array}$ & $3 x /$ day & IVT & Smartphone & $\begin{array}{c}\text { Alert: } \\
\text { Abnormal }\end{array}$ \\
\hline
\end{tabular}




\begin{tabular}{|c|c|c|c|c|c|c|c|c|c|c|c|}
\hline $\begin{array}{c}\text { Merone } \\
{[51]}\end{array}$ & $\begin{array}{c}201 \\
7\end{array}$ & / & 22 & & I & & $\begin{array}{c}6 \\
\text { months }\end{array}$ & $3 x /$ day & I & Smartphone & $\begin{array}{l}\text { Retrospecti } \\
\text { ve analysis }\end{array}$ \\
\hline $\begin{array}{c}\text { Pedone } \\
{[87]}\end{array}$ & $\begin{array}{c}201 \\
3\end{array}$ & 1 & 50 & 49 & $\begin{array}{c}53 \\
\pm\end{array}$ & $\begin{array}{c}55 \\
\pm\end{array}$ & $\begin{array}{c}9 \\
\text { months }\end{array}$ & $\begin{array}{c}5 \mathrm{x} / 3 \text { hour } \\
\mathrm{s}\end{array}$ & Nonin & Smartphone & $\begin{array}{c}\text { Alert: } \\
\text { Abnormal }\end{array}$ \\
\hline Faria [28] & $\begin{array}{c}201 \\
4\end{array}$ & $\begin{array}{c}\text { TELEMOL } \\
\text { D }\end{array}$ & $22 *$ & & I & & $\begin{array}{l}7.6 \pm \\
4.5\end{array}$ & $\begin{array}{c}\text { Continuo } \\
\text { us }\end{array}$ & $\begin{array}{l}\text { Nonin } \\
\text { Avant }\end{array}$ & Smartphone & $\begin{array}{c}\text { Alert: } \\
\text { Abnormal }\end{array}$ \\
\hline
\end{tabular}

${ }^{1}$ Indented articles originate from the same study as the article above. The articles are sorted by measuring frequency and study duration; SD - Standard Deviation; RC - Remote consultation; TM - Telemonitoring group; UC - Usual care group; FEV1\%pred - Percentage predicted of the forced expiratory volume in 1 second; * Non-COPD participants excluded; **Non-COPD participants included; MCWC - Medical Concierge Wrist Clinic 
Table 2: Detection or prediction of exacerbations based on $\mathrm{SpO}_{2}$ and other physiological measurements ${ }^{2}$

\begin{tabular}{|c|c|c|c|c|}
\hline Author & Year & $\mathrm{SpO}_{2}$ & Other physiological variables & Combination of variables \\
\hline $\begin{array}{l}\text { Martin- } \\
\text { Lesende } \\
{[44]}\end{array}$ & 2013 & $\begin{array}{l}74.3 \% \text { of all } \mathrm{SpO}_{2^{-}} \\
\text {based alerts were } \\
\text { generated in the } \\
\text { five days prior to a } \\
\text { hospitalization }\end{array}$ & $\begin{array}{c}\text { RR: } 69.4 \% \text { alerts generated prior } \\
\text { hospitalization } \\
\text { Systolic BP: } 38.9 \% \text { alerts generated } \\
\text { prior hospitalization } \\
\text { Diastolic BP: } 36.1 \% \text { alerts generated } \\
\text { prior hospitalization } \\
\text { HR: } 27.8 \% \text { alerts generated prior } \\
\text { hospitalization } \\
\text { Body weight: } 31 \% \text { alerts generated prior } \\
\text { hospitalization } \\
\text { Temperature: } 27.8 \% \text { alerts generated } \\
\text { prior hospitalization }\end{array}$ & / \\
\hline $\begin{array}{l}\text { Segrelles } \\
\text { Calvo [45] }\end{array}$ & 2014 & $\begin{array}{l}\mathrm{SpO}_{2} \text { triggered an } \\
\text { alert in } 30 \text { of } 50 \\
\text { detected } \\
\text { exacerbations }\end{array}$ & $\begin{array}{l}\text { PEF: } 7 \text { of } 50 \text { alerts } \\
\text { BP: } 4 \text { of } 50 \text { alerts }\end{array}$ & \\
\hline Burton [53] & 2015 & $\begin{array}{c}\mathrm{SpO}_{2} \text { can } \\
\text { differentiate } \\
\text { between } \\
\text { exacerbation days } \\
\text { and usual days } \\
\text { (p-value }=0.002 \text { ) } \\
\mathrm{SpO}_{2} \text { cannot } \\
\text { differentiate } \\
\text { between } \\
\text { exacerbation days } \\
\text { and isolated bad } \\
\text { days (p-value = } \\
0.61 \text { ) }\end{array}$ & $\begin{array}{r}\text { HR: cannot differentiate between } \\
\text { exacerbation days and usual days } \\
(\mathrm{p} \text {-value }=0.12) \\
\text { HR: cannot differentiate between } \\
\text { exacerbation days and isolated bad de } \\
(\mathrm{p} \text {-value }=0.22)\end{array}$ & 1 \\
\hline $\begin{array}{l}\text { Brown- } \\
\text { Connolly } \\
{[32]}\end{array}$ & 2014 & $\begin{array}{l}\text { Exacerbation } \\
\text { prediction based on } \\
\text { measured } \mathrm{SpO}_{2} \\
\mathrm{AUC}=0.693\end{array}$ & $\begin{array}{c}\text { Exacerbation prediction based on } \\
\text { measured } \\
\text { BP: AUC }=0.553 \\
\text { HR: AUC }=0.540 \\
\text { Systolic BP: AUC }=0.540 \\
\text { Diastolic BP: } \text { AUC }=0.527\end{array}$ & 1 \\
\hline Shah [34] & 2017 & $\begin{array}{l}\text { Exacerbation } \\
\text { prediction based on } \\
\text { mean and linear fit } \\
\text { gradient over seven } \\
\text { days of } \mathrm{SpO}_{2} \\
\mathrm{AUC}=0.658\end{array}$ & $\begin{array}{l}\text { Exacerbation prediction based on mean } \\
\text { and linear fit gradient over seven days } \\
\text { of: } \\
\text { RR: } A U C=0.605 \\
\text { HR: AUC }=0.578\end{array}$ & $\begin{array}{c}\text { Exacerbation prediction based on mean } \\
\text { and linear fit gradient over seven days } \\
\text { of: } \\
\mathrm{SpO}_{2}+\mathrm{HR}: \mathrm{AUC}=0.664 \\
\mathrm{SpO}_{2}+\mathrm{RR}: \mathrm{AUC}=0.672 \\
\mathrm{SpO}_{2}+\mathrm{HR}+\mathrm{RR}: \mathrm{AUC}=0.682\end{array}$ \\
\hline Jensen [49] & 2012 & $\begin{array}{c}\text { Exacerbation } \\
\text { prediction based on } \\
\mathrm{SD} \text { over } 25 \text { days of } \\
\mathrm{SpO}_{2} \\
\mathrm{AUC}=0.61\end{array}$ & 1 & $\begin{array}{c}\text { Exacerbation prediction based on } \\
\text { linear regression between } \mathrm{SpO}_{2} \text { and } \mathrm{HR} \\
\text { over } 30 \text { days: } \\
\text { AUC }=0.78 \\
\mathrm{SpO}_{2} \mathrm{SD} \text { over } 25 \text { days }+ \text { linear } \\
\text { regression between } \mathrm{SpO}_{2} \text { and } \mathrm{HR} \text { over } \\
30 \text { days: } \mathrm{AUC}=0.73\end{array}$ \\
\hline Hurst [29] & 2010 & $\begin{array}{c}\text { Exacerbation } \\
\text { prediction based on } \\
\text { measured } \mathrm{SpO}_{2} \\
\mathrm{AUC}=0.712\end{array}$ & $\begin{array}{c}\text { Exacerbation prediction based on } \\
\text { measured } \\
\text { HR: } A U C=0.819 \\
\text { PEF: } A U C=0.805\end{array}$ & $\begin{array}{c}\text { Exacerbation prediction based on } \\
\text { oximetry score }\left(\mathrm{SpO}_{2}+\mathrm{HR}\right): \mathrm{AUC}= \\
0.849 \\
\text { oximetry-PEF score }\left(\mathrm{SpO}_{2}+\mathrm{HR}+\right. \\
\text { PEF): AUC }=0.897\end{array}$ \\
\hline $\begin{array}{l}\text { Mohktar } \\
{[33]}\end{array}$ & 2015 & $\begin{array}{c}\text { Exacerbation } \\
\text { prediction based on } \\
\text { distribution mean } \\
\text { of } \mathrm{SpO}_{2} \text { over } 30 \\
\text { days } \\
\text { Cohen's kappa = }\end{array}$ & $\begin{array}{c}\text { Exacerbation prediction based on } \\
\text { FEV1 SD: Cohen's kappa }=0.21 \\
\text { measured weight: Cohen's kappa }=0.21 \\
\text { measured FEV1: Cohen's kappa }=0.18 \\
\text { weight distribution mean: Cohen's } \\
\text { kappa }=0.15\end{array}$ & $\begin{array}{c}\text { Exacerbation prediction based on } \\
\text { features of } \mathrm{SpO}_{2}, \mathrm{FEV} 1 \text {, weight, } \\
\text { temperature } \mathrm{HR}, \mathrm{RR} \text { : } \\
\text { Cohen's kappa }=0.42 \\
\text { Accuracy }=71.8 \%\end{array}$ \\
\hline
\end{tabular}




\begin{tabular}{|c|c|c|c|}
\hline & 0.27 & weight SD: Cohen's kappa $=0.13$ \\
& & temperature percentage change: Cohen's & kappa $=0.13$ \\
& & FEV1 percentage change: 0.13 & \\
& & FEV1 distribution mean: 0.11 & \\
\hline
\end{tabular}

${ }^{2} \mathrm{SpO}_{2}$ - Oxygen saturation; $\mathrm{RR}$ - Respiratory rate; $\mathrm{BP}$ - Blood pressure; HR - Heart rate; PEF - Peak expiratory flow; AUC - Area under the curve;

FEV1 - Forced expiratory volume in 1 second; SD - Standard Deviation

\section{Key issues}

- Long-term follow-up of COPD patients using daily spot check measurements of oxygen saturation $\left(\mathrm{SpO}_{2}\right)$ is practically feasible.

- Very few studies specified protocols to perform $\mathrm{SpO}_{2}$ measurements.

- In many studies, deviating $\mathrm{SpO}_{2}$ values were used to raise alerts that led to immediate action from healthcare professionals. Other studies developed methods to predict exacerbations through retrospective analysis of the measured $\mathrm{SpO}_{2}$ values.

- Little information was available about the exact implementation and performance of $\mathrm{SpO}_{2}$ alerts.

- No firm conclusions can be drawn about the real value of $\mathrm{SpO}_{2}$ measurements. Nevertheless, the few studies that assessed the value of $\mathrm{SpO}_{2}$ measurements indicated that these measurements could be valuable for exacerbation detections or predictions.

- Future research could optimize alerts based on daily measured $\mathrm{SpO}_{2}$ by using individualized, time-dependent thresholds or predictive algorithms to account for individual differences and $\mathrm{SpO}_{2}$ baseline changes.

- The value of performing more continuous measurements should be examined, as these measurements can make it possible to examine the $\mathrm{SpO}_{2}$ dynamics and account for factors that acutely influence the measurements (e.g. physical activity or sleep). 


\section{Funding}

This research is part of a $\mathrm{PhD}$ research funded by Flemish Institute for Technological Research (VITO), Mol, Belgium.

\section{Declaration of interests}

MA Spruit discloses receiving numeration for consultancy and/or lectures from Boehringer Ingleheim, GlaxoSmithKline and AstraZeneca outside the scope of this work. The authors have no other relevant affiliations or financial involvement with any organization or entity with a financial interest in or financial conflict with the subject matter or materials discussed in the manuscript apart from those disclosed. Peer reviewers on this manuscript have no relevant financial or other relationships to disclose. 


\section{References}

\section{Reference annotations}

* Of interest

** Of considerable interest

[1] World Health Organization. Chronic respiratory diseases [Internet]. [cited 2016 Nov 3]. Available from: http://www.who.int/respiratory/about_topic/en/.

[2] World Health Organization. COPD [Internet]. [cited 2016 Nov 3]. Available from: http://www.who.int/respiratory/copd/en/.

[3] European Respiratory Society. The European Lung White Book: Respiratory Health and Disease in Europe. Sheffield; 2013. p. 16-27.

[4] Lopez-Campos JL, Tan W, Soriano JB. Global burden of COPD. Respirology. 2016;21:14-23.

[5] Rodriguez-roisin R. Toward a Consensus Definition for COPD Exacerbations. Chest. 2000;117:398S-401S.

[6] Global Initiative for Chronic Obstructive Lung Disease (GOLD). Global strategy for the diagnosis, management, and prevention of chronic obstructive pulmonary disease [Internet]. 2016 [cited 2016 Oct 1]. Available from: www.goldcopd.org.

[7] Kent BD, Mitchell PD, Mcnicholas WT. Hypoxemia in patients with COPD: Cause, effects, and disease progression. Int. J. COPD. 2011;6:199-208.

[8] Stoller JK, Panos RJ, Krachman S, et al. Oxygen therapy for patients with COPD: Current evidence and the long-term oxygen treatment trial. Chest. 2010;138:179-187.

[9] Pretto JJ, Roebuck T, Beckert L, et al. Clinical use of pulse oximetry: Official guidelines from the Thoracic Society of Australia and New Zealand. Respirology. 2014;19:38-46.

[10] Alian AA, Shelley KH. Photoplethysmography. Best Pract. Res. Clin. Anaesthesiol. 2014;28:395-406.

[11] Kelly AM, McAlpine R, Kyle E. How accurate are pulse oximeters in patients with acute exacerbations of chronic obstructive airways disease? Respir. Med. 2001;95:336-340.

[12] Al Rajeh A, Hurst J. Monitoring of Physiological Parameters to Predict Exacerbations of Chronic Obstructive Pulmonary Disease (COPD): A Systematic Review. J. Clin. Med. 2016;5:108.

[13] Cruz J, Brooks D, Marques A. Home telemonitoring in COPD: A systematic review of methodologies and patients' adherence. Int. J. Med. Inform. 2014;83:249-263.

[14] Paré G, Jaana M, Sicotte C. Systematic Review of Home Telemonitoring for Chronic Diseases: The Evidence Base. J. Am. Med. Informatics Assoc. 2007;14:269-277.

[15] Wilkinson TMA, Donaldson GC, Hurst JR, et al. Early therapy improves outcomes of exacerbations of chronic 
obstructive pulmonary disease. Am. J. Respir. Crit. Care Med. 2004;169:1298-1303.

[16] Stroetmann KA, Kubitschke L, Robinson S, et al. How can telehealth help in the provision of integrated care? [Internet]. World Heal. Organ. 2010. p. 39. Available from:

http://www.euro.who.int/_data/assets/pdf_file/0011/120998/E94265.pdf.

[17] Schou L, Ostergaard B, Rasmussen LS, et al. Telemedicine-Based Treatment Versus Hospitalization in Patients with Severe Chronic Obstructive Pulmonary Disease and Exacerbation: Effect on Cognitive Function. A Randomized Clinical Trial. Telemed. E-Health. 2014;20:640-646.

[18] Schou L, Ostergaard B, Rydahl-Hansen S, et al. A randomised trial of telemedicine-based treatment versus conventional hospitalisation in patients with severe COPD and exacerbation - effect on self-reported outcome. J. Telemed. Telecare. 2013;19:160-165.

[19] Jakobsen AS, Laursen LC, Rydahl-Hansen S, et al. Home-Based Telehealth Hospitalization for Exacerbation of Chronic Obstructive Pulmonary Disease: Findings from “The Virtual Hospital” Trial. Telemed. e-Health. 2015;21:364-373.

[20] Emme C, Mortensen EL, Rydahl-Hansen S, et al. The impact of virtual admission on self-efficacy in patients with chronic obstructive pulmonary disease - a randomised clinical trial. J. Clin. Nurs. 2014;23:3124-3137.

[21] Gottlieb M, Marsaa K, Andreassen H, et al. Feasibility of a telecare solution for patients admitted with COPD exacerbation: screening data from a pulmonary ward in a university hospital. Eur Clin Respir J. 2014;1:24193.

[22] Saleh S, Larsen JP, Bergsaker-Aspoy J, et al. Re-admissions to hospital and patient satisfaction among patients with chronic obstructive pulmonary disease after telemedicine video consultation - a retrospective pilot study. Multidiscip. Respir. Med. 2014;9:6.

[23] Sorknaes AD, Bech M, Madsen H, et al. The effect of real-time teleconsultations between hospital-based nurses and patients with severe COPD discharged after an exacerbation. J. Telemed. Telecare. 2013;19:466-474.

[24] Vitacca M, Assoni G, Pizzocaro P, et al. A pilot study of nurse-led, home monitoring for patients with chronic respiratory failure and with mechanical ventilation assistance. J. Telemed. Telecare. 2006;12:337-342.

[25] Vitacca M, Bazza A, Bianchi L, et al. Tele-assistance in chronic respiratory failure: patients' characterization and staff workload of 5-year activity. Telemed. J. e-Health. 2010;16:299-305.

[26] Vitacca M, Bianchi L, Guerra A, et al. Tele-assistance in chronic respiratory failure patients: a randomised clinical trial. Eur. Respir. J. 2009;33:411-418.

[27] Koizumi T, Takizawa M, Nakai K, et al. Trial of remote telemedicine support for patients with chronic respiratory failure at home through a multistation communication system. Telemed. J. e-Health. 2005;11:481-486.

[28] Faria I, Gaspar C, Zamith M, et al. TELEMOLD Project: Oximetry and Exercise Telemonitoring to Improve Long-Term Oxygen Therapy. Telemed. e-Health. 2014;20:626-632. 


\section{* The only included article that performs continuous oxygen saturation measurements}

[29] Hurst JR, Donaldson GC, Quint JK, et al. Domiciliary pulse-oximetry at exacerbation of chronic obstructive pulmonary disease: prospective pilot study. Bmc Pulm. Med. 2010;10:52.

[30] Jódar-Sánchez F, Ortega F, Parra C, et al. Implementation of a telehealth programme for patients with severe chronic obstructive pulmonary disease treated with long-term oxygen therapy. J. Telemed. Telecare. 2013;19:11-17.

[31] Shany T, Hession M, Pryce D, et al. A small-scale randomised controlled trial of home telemonitoring in patients with severe chronic obstructive pulmonary disease. J. Telemed. Telecare. 2016;0:1-7.

[32] Brown-Connolly NE. A better way to evaluate remote monitoring programs in chronic disease care: receiver operating characteristic analysis. Telemed. E-Health. 2014;20:1143-1149.

* The only included article that used retrospective analyses to calculate an optimal generic

\section{threshold value}

[33] Mohktar MS, Redmond SJ, Antoniades NC, et al. Predicting the risk of exacerbation in patients with chronic obstructive pulmonary disease using home telehealth measurement data. Artif. Intell. Med. 2015;63:51-59.

[34] Shah SA, Velardo C, Farmer A, et al. Exacerbations in Chronic Obstructive Pulmonary Disease: Identification and Prediction Using a Digital Health System. J. Med. Internet Res. 2017;19:e69.

* The only included article that assessed the value of $\mathrm{SpO}_{2}$ measurements in telemonitoring applications based on the results of measurements on at least 100 COPD patients

[35] Achelrod D, Schreyogg J, Stargardt T. Health-economic evaluation of home telemonitoring for COPD in Germany: evidence from a large population-based cohort. Eur J Heal. Econ. 2016;18:869-882.

[36] Lewis KE, Annandale JA, Warm DL, et al. Home telemonitoring and quality of life in stable, optimised chronic obstructive pulmonary disease. J. Telemed. Telecare. 2010;16:253-259.

[37] Lewis KE, Annandale JA, Warm DL, et al. Does Home Telemonitoring after Pulmonary Rehabilitation Reduce Healtheare Use in Optimized COPD?? A Pilot Randomized Trial. COPD-Journal Chronic Obstr. Pulm. Dis. 2010;7:4450.

[38] MacNab M, Lee SH, McCloughan L, et al. Oximetry-supported self-management for chronic obstructive pulmonary disease: mixed method feasibility pilot project. BMC Health Serv. Res. 2015;15:485.

[39] Koff P. B, Jones RH, Cashman JM, et al. Proactive integrated care improves quality of life in patients with COPD. Eur. Respir. J. 2009;33:1031-1038.

[40] Ho TW, Huang CT, Chiu HC, et al. Effectiveness of Telemonitoring in Patients with Chronic Obstructive Pulmonary Disease in Taiwan-A Randomized Controlled Trial. Sci. Rep. 2016. 
[41] Colantonio S, Govoni L, Dellaca RL, et al. Decision Making Concepts for the Remote, Personalized Evaluation of COPD Patients' Health Status. Methods Inf Med. 2015;54:240-247.

[42] Chatwin M, Hawkins G, Panicchia L, et al. Randomised crossover trial of telemonitoring in chronic respiratory patients (TeleCRAFT trial). Thorax. 2016;71:305-311.

[43] Lamothe L, Fortin J-P, Labbe F, et al. Impacts of telehomecare on patients, providers, and organizations. Telemed. J. eHealth. 2006;12:363-369.

[44] Martín-Lesende I, Orruño E, Bilbao A, et al. Impact of telemonitoring home care patients with heart failure or chronic lung disease from primary care on healthcare resource use (the TELBIL study randomised controlled trial). BMC Health Serv. Res. 2013;13:118.

[45] Segrelles Calvo G, Gomez-Suarez C, Soriano JB, et al. A home telehealth program for patients with severe COPD: The PROMETE study. Respir. Med. 2014;108:453-462.

[46] Velardo C, Shah SA, Gibson O, et al. Digital health system for personalised COPD long-term management. BMC Med. Inform. Decis. Mak. 2017;17:19.

[47] Hardinge M, Rutter H, Velardo C, et al. Using a mobile health application to support self-management in chronic obstructive pulmonary disease: a six-month cohort study. BMC Med. Inform. Decis. Mak. 2015;15:46.

[48] Williams V, Price J, Hardinge M, et al. Using a mobile health application to support self-management in COPD: a quality study. Br. J. Gen. Pract. 2014;64:392-400.

[49] Jensen MH, Cichosz SL, Dinesen B, et al. Moving prediction of exacerbation in chronic obstructive pulmonary disease for patients in telecare. J. Telemed. Telecare. 2012;18:99-103.

[50] Riis HC, Jensen MH, Cichosz SL, et al. Prediction of exacerbation onset in chronic obstructive pulmonary disease patients. J. Telemed. Telecare. 2016;40:1-7.

[51] Merone M, Pedone C, Capasso G, et al. A decision support system for tele-monitoring COPD-related worrisome events. IEEE J Biomed Heal. Inf. 2017;21:296-302.

[52] Clarke M, Gokalp H, Fursse J, et al. Dynamic Threshold Analysis of Daily Oxygen Saturation for Improved Management of COPD Patients. IEEE J. Biomed. Heal. Informatics. 2016;20:1352-1360.

* The only included article that approached the daily oxygen saturation measurements as a time series and used specific time series analyses on the measured values

[53] Burton C, Pinnock H, McKinstry B. Changes in telemonitored physiological variables and symptoms prior to exacerbations of chronic obstructive pulmonary disease. J. Telemed. Telecare. 2015;21:29-36.

[54] Venter A., Burns R., Hefford M., et al. Results of a telehealth-enabled chronic care management service to support people with long-term conditions at home. J. Telemed. Telecare. 2012;18:172-175. 
[55] Lilholt PH, Emtekær LK, Haesum LKE, et al. Exploring User Experience of a Telehealth System for the Danish TeleCare North Trial. Stud. Health Technol. Inform. 2015;210:301-305.

[56] Lilholt PH, Haesum LKE, Ehlers LH, et al. Specific technological communication skills and functional health literacy have no influence on self-reported benefits from enrollment in the TeleCare North trial. Int J Med Inf. 2016;91:60-66.

[57] Haesum LKE, Ehlers L, Hejlesen OK. Interaction between functional health literacy and telehomecare: Short-term effects from a randomized trial. Nurs. Health Sci. 2016;18:328-333.

[58] Stausholm MN, Egmose A, Dahl SC, et al. Stratification of telehealthcare for patients with chronic obstructive pulmonary disease using a predictive algorithm as decision support: A pilot study. J. Telemed. Telecare. 2016;0:2016.

[59] Finkelstein SM, Speedie SM, Demiris G, et al. Telehomecare: Quality, Perception, Satisfaction. Telemed. J. e-Health. 2004;10:122-128.

[60] Finkelstein SM, Speedie SM, Potthoff S. Home Telehealth Improves Clinical Outcomes at Lower Cost for Home Healthcare. Telemed. J. e-Health. 2006;12:128-136.

[61] Smaradottir B, Gerdes M, Fensli R, et al. Usability Evaluation of a COPD Remote Monitoring Application. Stud. Health Technol. Inform. 2015;210:845-849.

[62] van der Heijden M, Lucas PJF, Lijnse B, et al. An autonomous mobile system for the management of COPD. J. Biomed. Inform. 2013;46:458-469.

[63] Cardozo L, Steinberg J. Telemedicine for recently discharged older patients. Telemed. J. e-Health. 2010;16:49-55.

[64] Hamad GA, Crooks M, Morice AH. The value of telehealth in the early detection of chronic obstructive pulmonary disease exacerbations: A prospective observational study. Health Informatics J. 2016;22:406-413.

[65] Davis C, Bender M, Smith T, et al. Feasibility and Acute Care Utilization Outcomes of a Post-Acute Transitional Telemonitoring Program for Underserved Chronic Disease Patients. Telemed. J. e-Health. 2015;21:705-713.

[66] Gellis ZD, Kenaley B, McGinty J, et al. Outcomes of a Telehealth Intervention for Homebound Older Adults With Heart or Chronic Respiratory Failure: A Randomized Controlled Trial. Gerontologist. 2012;52:541-552.

[67] Gellis ZD, Kenaley BL, Have T Ten, et al. Integrated Telehealth Care for Chronic Illness and Depression in Geriatric Home Care Patients: The Integrated Telehealth Education and Activation of Mood (I-TEAM) Study. J. Am. Geriatr. Soc. 2014;62:889-895.

[68] Jodar-Sanchez F, Ortega F, Parra C, et al. Cost-utility analysis of a telehealth programme for patients with severe chronic obstructive pulmonary disease treated with long-term oxygen therapy. J. Telemed. Telecare. 2014;20:307-316.

[69] Ure J, Pinnock H, Hanley J, et al. Piloting tele-monitoring in COPD: A mixed methods exploration of issues in design and implementation. Prim. Care Respir. J. 2012;21:57-64.

[70] Teijeiro T, Felix P, Presedo J, et al. An open platform for the protocolization of home medical supervision. Expert Syst. 
Appl. [Internet]. 2013;40:2607-2614. Available from: http://dx.doi.org/10.1016/j.eswa.2012.11.001.

[71] De San Miguel K, Smith J, Lewin G. Telehealth remote monitoring for community-dwelling older adults with chronic obstructive pulmonary disease. Telemed. J. e-Health. 2013;19:652-657.

[72] Ding H, Karunanithi M, Kanagasingam Y, et al. A pilot study of a mobile-phone-based home monitoring system to assist in remote interventions in cases of acute exacerbation of COPD. J. Telemed. Telecare. 2014;20:128-134.

[73] Kenealy TW, Parsons MJG, Rouse APB, et al. Telecare for diabetes, CHF or COPD: effect on quality of life, hospital use and costs. A randomised controlled trial and qualitative evaluation. PLoS One. 2015;10:e0116188.

[74] McDowell JE, McClean S, FitzGibbon F, et al. A randomised clinical trial of the effectiveness of home-based health care with telemonitoring in patients with COPD. J. Telemed. Telecare. 2015;21:80-87.

[75] Zamith M, Cardoso T, Matias I, et al. Home telemonitoring of severe chronic respiratory insufficient and asthmatic patients. Rev. Port. Pneumol. 2009;15:385-417.

[76] Steventon A, Ariti C, Fisher E, et al. Effect of telehealth on hospital utilisation and mortality in routine clinical practice: a matched control cohort study in an early adopter site. BMJ Open. 2016;6:e009221.

[77] Antoniades NC, Rochford PD, Pretto JJ, et al. Pilot study of remote telemonitoring in COPD. Telemed. J. e-Health. 2012;18:634-640.

[78] Pinnock H, Hanley J, McCloughan L, et al. Effectiveness of telemonitoring integrated into existing clinical services on hospital admission for exacerbation of chronic obstructive pulmonary disease: researcher blind, multicentre, randomised controlled trial. BMJ-British Med. J. 2013;347:f6070.

[79] Stoddart A, van der Pol M, Pinnock H, et al. Telemonitoring for chronic obstructive pulmonary disease: a cost and costutility analysis of a randomised controlled trial. J. Telemed. Telecare. 2015;21:108-118.

[80] Steventon A, Bardsley M, Billings J, et al. Effect of telehealth on use of secondary care and mortality: findings from the Whole System Demonstrator cluster randomised trial. BMJ-British Med. J. 2012;344:e3874.

[81] Bardsley M, Steventon A, Doll H. Impact of telehealth on general practice contacts: findings from the whole systems demonstrator cluster randomised trial. BMC Health Serv. Res. 2013;13:395.

[82] Henderson C, Knapp M, Fernandez J-L, et al. Cost effectiveness of telehealth for patients with long term conditions (Whole Systems Demonstrator telehealth questionnaire study): nested economic evaluation in a pragmatic, cluster randomised controlled trial. BMJ-British Med. J. 2013;346:f1035.

[83] Rixon L, Hirani SP, Cartwright M, et al. A RCT of telehealth for COPD patient's Quality of life: The Whole System Demonstrator Evaluation. Clin. Respir. J. 2015;0:000-000.

[84] Vianello A, Fusello M, Gubian L, et al. Home telemonitoring for patients with acute exacerbation of chronic obstructive pulmonary disease: a randomized controlled trial. Bmc Pulm. Med. 2016;16:157. 
[85] Esteban C, Moraza J, Iriberri M, et al. Outcomes of a telemonitoring-based program (telEPOC) in frequently hospitalized COPD patients. Int. J. Chron. Obstruct. Pulmon. Dis. 2016;11:2919-2930.

[86] Chau JP-CC, Lee DT-F, Yu DS-F, et al. A feasibility study to investigate the acceptability and potential effectiveness of a telecare service for older people with chronic obstructive pulmonary disease. Int. J. Med. Inform. 2012;81:674-682.

[87] Pedone C, Chiurco D, Scarlata S, et al. Efficacy of multiparametric telemonitoring on respiratory outcomes in elderly people with COPD: a randomized controlled trial. BMC Health Serv. Res. 2013;13:82.

[88] Barrecheguren M, Miravitlles M. COPD heterogeneity: implications for management. Multidiscip. Respir. Med. 2016;11:14.

[89] Tang J, Mandrusiak A, Russell T. The feasibility and validity of a remote pulse oximetry system for pulmonary rehabilitation: A pilot study. Int. J. Telemed. Appl. 2012;2012.

[90] Alvarez D, Hornero R, Marcos JV, et al. Multivariate analysis of blood oxygen saturation recordings in obstructive sleep apnea diagnosis. IEEE Trans. Biomed. Eng. 2010;57:2816-2824.

[91] Marcos JV, Hornero R, Álvarez D, et al. Automated prediction of the apnea-hypopnea index from nocturnal oximetry recordings. IEEE Trans. Biomed. Eng. 2012;59:141-149. 